\title{
Effect of breed, chilling duration and processed product on the quality
} characteristics of mutton

${ }^{*}$ Salihu, D. Y., ${ }^{2}$ Duru, S., ${ }^{2}$ Abdu, S. B., ${ }^{3}$ Munza, B. M., ${ }^{1}$ Abdu, M. B., ${ }^{4}$ Sadiq, A. A. and

${ }^{2}$ Bamus, O. A.

${ }^{I}$ Federal College of Animal Health and Production Technology, Vom, Jos, Nigeria

${ }^{2}$ Department of Animal Science, Ahmadu Bello University, Zaria, Nigeria

${ }^{3}$ Department of Animal Science, University of Maiduguri, Maiduguri, Nigeria

${ }^{4}$ Department of Agricultural Education, Federal College of Education, Zuba-Abuja, Nigeria,

*Corresponding author:bellomunza@gmail.com; +2347038737250

Abstract

An experiment was conducted to evaluate the effect of breed, chilling duration and processed product on the quality characteristics of mutton. A total of nine (9) mature rams of 12 months of age $(25 \mathrm{Kg})$ managed on the same system were used. The animals were kept for 24 hours where only water was provided to clear the gut content before slaughter. The experiment was carried out in a factorial arrangement (3 $\times 3 \times 3)$ of a completely randomized design consisting of three breeds of sheep (Balami, Uda and Yankasa), three chilling durations (0, 24 and 48 hours) and three processed products (Balangu, Tsire and Tukunya). The result revealed that there was no significant $(P>0.05)$ effect of breed on proximate composition of fresh mutton. There was significant $(P<0.05)$ effect of processed product on the proximate composition of mutton. Moisture content was higher in Balangu (54.93\%), followed by Tukunya (51.74\%) and lower in Tsire (41.00\%). Crude protein content was higher in Balangu (33.83\%), followed by Tukunya (29.63\%) which was at par wih Tsire $(29.51 \%)$. Ash content was higher in Tsire (6.61\%), followed by Balangu (5.71\%) and lower in Tukunya $(3.69 \%)$. Significant $(P<0.05)$ chilling duration effect was obtained for bacteria count which was higher at 0 hours $\left(2.25 \times 10^{3} \mathrm{cfu} / \mathrm{g}\right)$ chilling, followed by 24 hours $\left(1.86 \times 10^{3}\right.$ cfu/g) chilling. The same trend was observed for coliform count in which higher value was obtained at 0 hours $\left(4.49 \times 10^{2} \mathrm{cfu} / \mathrm{g}\right)$ chilling, followed by 24 hours $\left(3.04 \times 10^{2} \mathrm{cfu} / \mathrm{g}\right)$ chilling and 48 hours $\left(2.93 \times 10^{2} \mathrm{cfu} / \mathrm{g}\right)$ chilling. Sensory properties of mutton from different breed differed significantly $(P<0.05)$ among processed products. The overall accepatability indicates that Tsire (7.60) product was more acceptable, followed by Tukunya (7.20) product while Balangu (6.86) product was less acceptable. The microbial count obtained from the study was within the acceptable range (<3.5 log HACCP 2002). It can be concluded that processed meat products (Tsire, Balangu and Tukunya) obtained from different breeds of Nigerian sheep (Balami, Uda and Yankasa) were not homogenous in their proximate composition. It is therefore recommended that fresh mutton should be chilled for 24 to 48 hours with little or no bacteria while fresh meat from the three breed of sheep (Balami, Uda and Yankasa) can be chilled for 24 to 48 hours with little or no bacteria and can be processed into different products (Tsire, Balangu and Tukunya).

Keywords: Breed, chilling, mutton, processed product and quality

\section{Introduction}

The domestic meat demand in Nigeria is increasing with increase in nutrition awareness and dispensable income.
Concern for quality meat is also increasing due to growing awareness and health concern. The main objection to consumption of locally processed meat 
products lies with the poor sanitary conditions associated with their production and handling practices. It has been reported that high micro-flora count observed in meat products is indicative of poor hygiene and handling practices (Bube, 2003; Kalla et al., 2005; Zahraddeen et al., 2007). However, it is suggested that the interval between processing and delivery to market be reduced, as this would limit the time for microbial multiplication. Ojewola and Onwuka (2001) stated that consumers are becoming increasingly prepared to pay for improved and better quality product from the local meat industry. The main livestock species producing red meat in Nigeria are sheep, goats, cattle and camels. Sheep play an important role in the social economic life of the people in Nigeria. In Sub Saharan Africa, sheep provide almost $30 \%$ of the meat consumed and around $16 \%$ of the milk produced (Bourn et al., 1994). Sheep contributes about $50 \%$ of the total domestically produced meat in Nigeria (Bourn et al., 1994). There are four main breeds of sheep native to Nigeria and these are Balami, Uda, Yankasa and West African Dwarf. Balami and Uda are kept in the semi-arid regions; West African Dwarf sheep in the south and Yankasa throughout the country (Bourn et al., 1994). These four breeds differ considerably in size, coat colour and other characteristics (Adu and Ngere, 1971). K'Opondo (2011) observed that methods of preserving meat include the use of high temperature (canning), low temperature (freezing), drying (sun-drying, smoking, use of radiation and chemical preservatives). This author also reported that drying reduces the moisture content to a level that prevents the growth of microorganisms especially fungi and bacteria. Chilling freshly harvested meat carcasses is necessary for food safety and quality purposes. Before mechanical refrigeration, meat either had to be consumed immediately after slaughter or be preserved through salting, curing, and/or smoking (Savell, 2012). With the advent of mechanical refrigeration and networks of refrigerated carriers, the production, processing, and distribution of carcasses and cuts were made more convenient and practical. It has been known for about a half century that cold temperatures at early postmortem could cause cold shortening or cold toughening of meat (Locker, 1985). K'Opondo (2011) reported that all handling and storage methods are therefore primarily concerned with minimizing microbial contamination and retarding microbial growth and activities. Meat products that are properly handled through good sanitation, maintenance of a clean production environment and heat treatment are prerequisites for extended shelf-life, reduced microbial load and improved acceptability.

Various methods are employed locally for the processing of meat for human consumption. But there is little information on these local indigenous meat products (Tsire, Balangu, Tukunya, ganda etc). Hence, it is therefore necessary to determine the effect of breed, chilling duration and processed meat products on meat quality.

\section{Materials and methods Experimental site}

The study was conducted at the Animal Products Laboratory of the Department of Animal Science, Ahmadu Bello University, Zaria. Zaria is located on Latitude $11^{\circ} 12^{\prime} \mathrm{N}$, Longitude $07^{\circ} 33^{\prime} \mathrm{E}$ at an altitude of $660 \mathrm{~m}$ above sea level, along Zaria-Funtua Road in the Northern Guinea Savannah zone of Nigeria (Ovimap, 2015). The climate is characterised by a defined wet and dry season. Wet season starts from April to early May and ends in late September to early October while the dry season lasts from October to April. The total annual rainfall 


\section{Salihu, Duru, Abdu, Munza, Abdu, Sadiq and Bamus}

ranges from 748.6 - $1156.7 \mathrm{~mm}$ with a long-term average of $1058.60 \mathrm{~mm}$. Maximum air temperature of $37^{\circ} \mathrm{C}$ are recorded in May and minimum air temperature of $11.5^{\circ} \mathrm{C}$ recorded in December/January and relative humidity of approximately $70 \%$ during the rainy season (IAR, 2018).

\section{Experimental design and management of animals}

The experiment was carried out in a Complete Randomized Design with factorial arrangement $(3 \times 3 \times 3)$ consisting of three breeds of sheep (Balami, Uda and Yankasa), three chilling durations $(0,24$ and 48hours slaughtering) and three processed products (Balangu, Tsire and Tukunya).

A total of nine (9) matured rams of twelve (12) months of age with an average body weight of $25 \mathrm{~kg}$ raised on the same diets and the same system were used. The animals were raised on semi intensive system of management. Concentrate (Table 1) was provided in the morning while the animals grazed on lush grasses in the evening. The animals were fattened for 90 days. Proper housing and sanitation was maintained throughout the period. The animals were sorted according to the three breed groups (Balami, Uda and Yankasa) group comprising of three (3) rams per group. The animals were inspected for diseases and disabilities. The animals were fasted for 24 hours without feed but water was made available before slaughtering.

\section{Slaughter and carcass dissection}

The animals were slaughtered according to the Halal standard procedure by severing the jugular vein and carotid arteries. The hair was removed by flaying as described by Fasae and Adelegan (2011). The internal organs (kidney, liver, heart and spleen) were carefully excise and weighed. The carcass was cut into primal cuts (shoulder, rack, loin, breast shank and flank) and each part was weighed. The dressing percentage was calculated as the ratio of dressed carcass weight to live weight in percentage.

\section{Mutton chilling}

Haier ${ }^{\circledR}$ Thermocool freezer model CCF$319 \mathrm{~T}$ at the Meat Science Laboratory was used for chilling between $2-7{ }^{\circ} \mathrm{C}$. The mutton was removed after each 24 and 48 hours for subsequent analyses (microbial count and characterization).

Table 1: Composition of concentrate supplement fed to experimental rams

\begin{tabular}{lc}
\hline Ingredients & Percentage (\%) \\
\hline Maize & 40.0 \\
Wheat offal & 31.5 \\
Cotton seed cake & 25.0 \\
Bone meal & 2.5 \\
Salt & 1.0 \\
Total & 100 \\
Calculated analysis (\%) & \\
Crude Protein & 13.63 \\
Metabolizable energy (Kcal/kg) & 2679.0 \\
\hline
\end{tabular}

\section{Meat processing}

Tsire

The preparation of the Tsire was as shown in Figure 5 as described by Igene and Mohammed (1983) and Uzeh et al. (2006). The spices comprised of Masoro, kanunfari, chitta, borkono, chittmaiyatsu, maggi, thyme and gishiri (Table 2). The fire was first set by burning the fire wood into red hot charcoal before staking the meat for roasting. The roasting was done on a local tukuba, a heap of soil built for the same 
purpose. The fresh meat staked on skewer was fixed into the soil around the glowing charcoal fire to roast (Figure 1).

\section{Balangu}

Balang $u$ is prepared from boneless meat of a sizeable cut, which was placed on a wet brown paper on a wire mesh over fire to roast. The pieces of meat were sliced into thin sheets not less than $1 \mathrm{~cm}$ in thickness. Groundnut oil and spices (Table 2) were added during roasting. The meat was turned continuously until it was well roasted as reported by Bube (2003) and Kalla et al. (2005) as shown in Figure 2.

\section{Tukunya}

This is similar to Balangu except that the sizeable cuts are enwrapped in a wet brown paper after adding groundnut oil and spices (Table 2). It was then placed on a wire mesh over fire to roast (Zahraddeen et al., 2006).

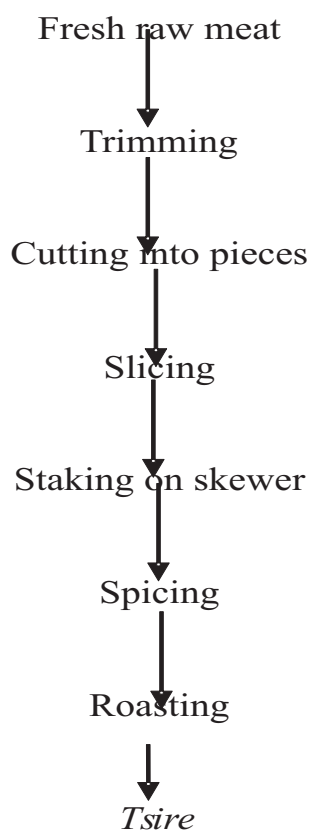

Figure 1: Preparation of Tsire Source: Bube (2003)

Table 2: Ingredient composition of spices used in the experiment

\begin{tabular}{lcc}
\hline Local/ Hausa name & Botanical/ English name & Proportion in mixture \\
\hline Masoro & Piper guinease & 12.0 \\
Kanunfari & Eugenia caryophyllata & 5.0 \\
Chitta & Afromomum meleginata & 5.0 \\
Borkono & Capsicum frustescens & 30.0 \\
Chitt maiyatsu & Zinginer officinale & 18.0 \\
Seasoning cube & Seasoning & 20.0 \\
Thyme & Seasoning & 5.0 \\
Gishiri & Salt (NaCl) & 5.0 \\
Total & & $\mathbf{1 0 0}$ \\
\hline
\end{tabular}




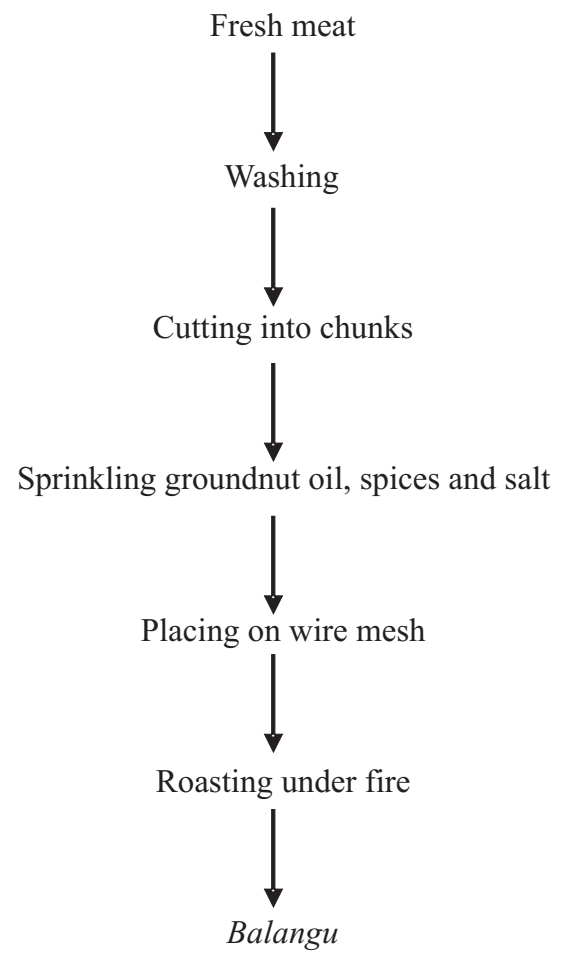

Figure 2: Preparation of Balangu

Source: Bube (2003)

\section{Sensory evaluation}

Balangu, Tsire and Tukunya were subjected to sensory evaluation for their acceptance. Thirty (30) panelists were trained for the assessment procedure two days prior to the evaluation; this was done using the method described by Bube (2003).

\section{Proximate composition}

For the proximate composition of the meat, about $50 \mathrm{~g}$ of meat cut from the loin was used for analysis. The indices analysed included moisture, dry matter, crude protein, ether extract and ash using AOAC (2005) procedure. The proximate analyses were carried out in the Nutritional Biochemistry Laboratory, National Veterinary Research Institute Vom, Plateau State.

\section{Microbial analysis}

Twenty five grams of the meat samples were put into $225 \mathrm{~mL}$ of 0.1 per cent buffered peptone water (diluent) and blended for 2 minutes. Serial dilutions were prepared by adding $1 \mathrm{ml}$ of the previous dilution to $9 \mathrm{ml}$ of the sterile diluents and homogenized in a stomacher for 2 minutes. This was carried out in the Scientific and Industrial Research Department, National Research Institute for Chemical Technology, Bassawa-Zaria, Kaduna State. Determination of total plate counts

$1 \mathrm{~mL}$ of each dilution was added to a sterile Petri dish and Plate Count Agar (kept at $45^{\circ} \mathrm{C}$ in a water bath) added and mixed thoroughly. The preparations were then allowed to gel and were finally incubated at $37^{\circ} \mathrm{C}$ for 24 hours and isolated distinct colonies were counted. Average counts obtained were multiplied by the dilution factor and expressed as colony forming unit 
per gram (cfu/g) (Fawole and Oso, 2001).

\section{Isolation of bacterial pathogens}

This was done by streaking on selective media for the most common meat bacterial pathogens. These include Salmonella spp., enteropathogenic $E$. coli and coagulase positive staphylococcus aureus.

\section{Detection of Salmonella}

A $10 \mathrm{~mL}$ of the homogenate was enriched by adding into $100 \mathrm{~mL}$ tetrathionate brilliant green broth and incubated at $37^{\circ} \mathrm{C}$ for 18 hours. The enrichment was subcultured onto Brilliant green agar, MacConkey agar and Salmonella-Shigella agar. Pink colonies on Brilliant green, colourless on MacConkey and pale colonies with black centres on SalmonellaShigella agar were taken into consideration (Fawole and Oso, 2001). The colonies were confirmed by biochemical test; TSI, Simmon's citrate agar and urea (Fawole and Oso, 2001). The TSI was examined for characteristics reactions that included alkaline slant/acid butt with hydrogen sulphide production. Typical Salmonella cultures show alkaline (red) slants and acid (yellow) butts with gas formation (bubbles) and (in about $90 \%$ of the cases) formation of hydrogen sulphide (blackening of the agar) (Yah et al., 2007).

\section{Detection of Escherichia coli}

For isolation of $E$. coli, $10 \mathrm{~mL}$ of the homogenate were inoculated on $1.5 \%$ peptone water and incubated at $37^{\circ} \mathrm{C}$ for 18 24 hours before been inoculated on MacConkey Sorbitol agar and MacConkey agar. Pathogenic E. coli produces colourless colonies (Alam et al., 2010). All isolates were identified as $E$. coli based on morphological and confirmed by biochemical characteristics (March and Ratnam, 1986; Bopp et al., 1999). Enteropathogenic E. coli was characterized by colourless colonies on MacConkey Sorbitol agar and indole positive test.

\section{Detection of Staphylococcus aureus}

A $10 \mathrm{~mL}$ diluents of the samples were inoculated on Mannitol salt agar and incubated at $37^{\circ} \mathrm{C}$ for $18-24$ hours (Okonko et al., 2010). Typical large, round, creamy and smooth colonies with golden yellow halo were isolated and sub-cultured. Presumptive diagnosis involved mannitol fermentation with an accumulation of acid production indicated by phenol red indicator turning yellow. These colonies were further confirmed by Gram staining, catalase test and coagulase test (Fawole and Oso, 2001).

\section{Detection of Pseudomonas aeruginosa}

Pseudomonas aeruginosa produced colourless colonies with characteristics greenish colour on MacConkey agar. The colonies were confirmed by biochemical tests; TSI, Simmon's citrate agar, urea and oxidase test. Pseudomonas aeruginosa was characterized by alkaline slunt and butt and the colonies were oxidase positive.

\section{Detection of Proteus vulgaris}

Proteus vulgaris produced characteristics pale dark centred colonies with swarming ends on Salmonella-Shigella agar and colourless colonies on MacConkey agar. Indole, citrate, urease test, reaction on TSI and Gram stain were further done to confirm the pathogen. Colonies with acidic slunt and butt with hydrogen sulphide production on TSI were characterized as Proteus vulgaris and were distinguished from Proteus mirabilis as they are indole positive. The landmark characteristic of Proteus spp., is the utilization of urea noted by the change of media to pink within a period of 2 hours.

\section{Statistical analysis}

The data collected from all the experiment were subjected to analysis of variance (ANOVA), using the General Linear Model Procedure of SAS (2005). The significant differences among the treatment means were separated using the Duncan's Multiple Range Test (Duncan, 1955) in the SAS Package. 


\section{Results and discussion}

Proximate composition of mutton as influenced by breed and processed products

The result revealed that there was no significant $(\mathrm{P}>0.05)$ effect of breed on proximate composition (Table 3). The proximate composition of fresh/raw meat did not vary with respect to moisture, crude protein, ether extract and ash among the breeds of sheep. The moisture, crude protein, ether extract and ash contents obtained in this study were in conformity with the findings of Balarabe (2016). It was however, reported that fresh adult mammalian muscle is about $75 \%$ moisture which varies considerably within species, breeds, muscle type and as intramuscular (marbling) reported by Sivasanker (2005). The non-significant $(\mathrm{P}>0.05)$ effect of breed in this study may be partly attributed to same species, sex, age, nutrition and other management practices. Balarabe (2016) reported mean moisture content of $72.54 \%$ in raw mutton which was in agreement with the values obtained in this present study with respect to moisture content values of Balami, Uda and Yankasa. The protein content values obtained in this study were higher than the values reported by Bube (2003) and Muhammed et al. (2010) but were similar with the values reported by Williams (2007) and Balarabe (2016) for mutton. The differences could be due to variation in intramuscular fats. However, ether extract contents in this study were lower than the values (15.37 and $19.33 \%)$ reported by Muhammad et al. (2010) but higher $(5.30-7.80 \%)$ than the findings of Bube (2003) and similar with the values $(6.98 \%)$ of Balarabe (2016). These variations may be attributed to the inherent nature of the various breeds in these studies. The ash content values in this study were similar to values reported by Muhammad et al. (2010) and Balarabe (2016). Proximate composition mutton differed significantly (P0.05) with processed products (Table 3). Moisture content and crude protein of Balangu were $5.81 \%$ and $25.36 \%$ and $12.42 \%$ and $12.77 \%$ higher $(\mathrm{P}<0.05)$ than Tukunya and Tsire of processed product, respectively. Ether extract of Tsire was $10.57 \%$ and $18.19 \%$ higher $(\mathrm{P}<0.05)$ than Tukunya and Balangu, respectively. While ash content obtained for Tsire was $13.62 \%$ and $44.18 \%$ higher than Balangu and Tukunya, respectively.

Table 3: Proximate composition of mutton as influenced by breed and processed products

\begin{tabular}{lcccc}
\hline Treatments & Moisture (\%) & Crude protein (\%) & Ether extract (\%) & Ash (\%) \\
\hline Breed & & & & \\
Balami & 72.54 & 20.93 & 6.98 & 2.50 \\
Uda & 70.48 & 21.00 & 8.13 & 3.12 \\
Yankasa & 72.43 & 20.55 & 6.77 & 2.81 \\
SEM & 1.20 & 1.30 & 1.20 & 1.20 \\
Processed Product & & & & \\
Balangu & $54.93^{\mathrm{a}}$ & $33.83^{\mathrm{a}}$ & $15.79^{\mathrm{c}}$ & $5.71^{\mathrm{b}}$ \\
Tsire & $41.00^{\mathrm{c}}$ & $29.51^{\mathrm{b}}$ & $19.30^{\mathrm{a}}$ & $6.61^{\mathrm{a}}$ \\
Tukunya & $51.74^{\mathrm{b}}$ & $29.63^{\mathrm{b}}$ & $17.26^{\mathrm{b}}$ & $3.69^{\mathrm{c}}$ \\
SEM & 1.20 & 1.30 & 1.20 & 1.20 \\
Interaction & & & \\
B x P & 1.000 & 1.000 & 1.000 & 1.000 \\
\hline abc means within column having different superscripts differed significantly (P<0.05), SEM = Standard error of \\
mean, B = Breed, P = Processed product
\end{tabular}




\section{Effect of breed, chilling duration and processed product on the quality characteristics of mutton}

The values of moisture content and ash obtained in this present study was higher than $35.00-39.09 \%$ and 1.80 and $2.86 \%$ reported by Ogbonna et al. (2012) for Suya. Whereas the crude protein recorded in this study was within $28.33-35.10 \%$ reported for Suya by Ogbonna et al. (2012). The ether extract was below $20.90-28.26 \%$ reported by the author. There was nonsignificant $(\mathrm{P}>0.05)$ interaction effect between breed and processed product.

Sensory properties of mutton as influenced by breed and processed product Sensory properties of mutton differed significantly $(\mathrm{P}<0.05)$ among breeds (Table 4). Balami meat is the most preferred for colour and with a slight high score (7.59). The preferences of Balami meat than other breeds may be due to breed difference. Adam et al. (2010) observed that meat colour is considered as an important parameter that attracts consumers to buy meat. Meat colour is also affected by method of slaughter as the level of blood left in the carcass. Meat colour has a powerful influence on consumer acceptance on food products especially meat products and serve as a visual indicator of meat quality (James, 1993). Similarly, Wheeler et al. (1991) reported that traditionally, meat colour has been the main criterion for evaluating freshness of retail meat which is a key component of consumer purchase decision of retail beef. Sensory properties of mutton differed significantly $(\mathrm{P}<0.05)$ among processed products (Table 4). Sensory attributes such as colour, flavour, tenderness, juiciness and acceptability are important components of consumer preference and meat consumption which may vary from breed, product and also the locality of the meat product. Meat colour is an important attribute in meat consumption as it positively relates to their sensory attribute of meat. Flavour is an index reported to be considered in meat sensory evaluation for its value in overall meat acceptance (Kalla et al., 2005). The processing method might have also influence its significant contribution on local meat industry and also for basis of meat products comparison in nutritional values as well as consumer acceptance in which Balami and Uda had the highest flavour among panelists. Balami (7.15) and Uda (7.31) were most preferred in terms of tenderness among the panelists. This could be due to the marbling effect of muscle fat. This was similarly reported by Bube (2003) and Balarabe (2016) who reported that the high score for mutton was due to marbling effect of muscle fat and that mode of marbling had a significant effect on meat tenderness. However, the sensory properties of meat like tenderness may have a significant impact on meat quality acceptability. This attribute (tenderness) is among the primary factors influencing consumer satisfaction. Tenderness of fat in meat is also considered as one of the decisive factors influencing the sensory quality of meat (Hocquette et al., 2010). Therefore, the observed difference in meat colour and tenderness in the present investigation might have being due to difference in marbling content in of these breeds. Balami meat had high score in juiciness and acceptability among panelists. This might be due to the marbling effect which has great influence on the colour, flavour and tenderness which lead to the overall acceptance of Balami meat. The high score values obtained for Tsire over other products for the sensory parameters evaluated might be due to the familiarity of the panelists to the product against Balangu and Tukunya. 
Salihu, Duru, Abdu, Munza, Abdu, Sadiq and Bamus

Table 4: Sensory properties of mutton as influenced by breed and processed product

\begin{tabular}{|c|c|c|c|c|c|}
\hline Treatments & Colour & Flavour & Tenderness & Juiciness & Acceptability \\
\hline \multicolumn{6}{|l|}{ Breed } \\
\hline Balami & $7.59^{\mathrm{a}}$ & $7.03^{\mathrm{a}}$ & $7.15^{\mathrm{a}}$ & $7.35^{\mathrm{a}}$ & $7.48^{\mathrm{a}}$ \\
\hline Uda & $7.38^{\mathrm{b}}$ & $7.19^{\mathrm{a}}$ & $7.31^{\mathrm{a}}$ & $6.86^{\mathrm{b}}$ & $7.23^{b}$ \\
\hline Yankasa & $7.24^{b}$ & $6.72^{\mathrm{b}}$ & $6.76^{\mathrm{b}}$ & $6.61^{\mathrm{c}}$ & $6.95^{c}$ \\
\hline SEM & 0.09 & 0.09 & 0.09 & 0.09 & 0.09 \\
\hline \multicolumn{6}{|c|}{ Processed Product } \\
\hline Balangu & $7.21^{b}$ & $6.64^{c}$ & $6.76^{\mathrm{b}}$ & $6.53^{c}$ & $6.86^{c}$ \\
\hline Tsire & $7.72^{\mathrm{a}}$ & $7.29^{a}$ & $7.19^{a}$ & $7.33^{\mathrm{a}}$ & $7.60^{\mathrm{a}}$ \\
\hline Tukunya & $7.27^{b}$ & $7.01^{b}$ & $7.37^{\mathrm{a}}$ & $6.96^{\mathrm{b}}$ & $7.20^{\mathrm{b}}$ \\
\hline SEM & 0.09 & 0.09 & 0.09 & 0.09 & 0.09 \\
\hline \multicolumn{6}{|l|}{ Interaction } \\
\hline$B \times P$ & 0.066 & 0.036 & 0.063 & 0.079 & 0.286 \\
\hline
\end{tabular}

Microbial count of mutton as influenced by breed and chilling duration

Microbial count of mutton differed significantly $(\mathrm{P}<0.05)$ among breeds (Table 5). The total viable bacteria count and coliform count obtained in this study were below the Nigeria Agency for Drug Administration and Control (NAFDAC) recommendation. The standard recommended by NAFDAC for public health is between $5.0 \times 10^{5}$ and $1.0 \times 10^{6}$ $\mathrm{cfu} / \mathrm{g}$. The meat obtained in this study was fit and safe for consumption. Coliforms are indicator organisms signifying contamination of the product by faecal matter (Taiwo et al., 2017). Significant $(\mathrm{P}<0.05)$ chilling duration effect was obtained for bacteria count (Table 5). The variation obtained during chilling duration for bacteria count and coliform count might be attributed to the chilling effect in which higher bacteria and coliform count were obtained before chilling. This agrees with the report of Taiwo et al. (2017) that the kind and number of microorganisms found on frozen fish depend on freezing temperature during storage and severity of freezing process with respect to lethality to microorganisms. Most food spoilage microorganisms grow rapidly at temperatures above $10^{\circ} \mathrm{C}$ while some food poisoning organisms grow slowly between $4.4^{\circ} \mathrm{C}$ and $-9.4^{\circ} \mathrm{C}$ provided the food is not solidly frozen (Sivasanker, 2005). These organisms will not produce food poisoning or disease but even below $-3.9^{\circ} \mathrm{C}$ cause the deterioration of the food quality. Below $9.4^{\circ} \mathrm{C}$ there is no significant growth of microorganisms in the food and there is a gradual reduction in their numbers due to slow death. But complete death of all the microorganisms does not occur merely due to low temperatures and when the food is thawed there can be a rapid multiplication of microorganisms (Sivasanker, 2005).

Identified bacteria in mutton as influenced by breed and chilling duration

Bacteria identified in mutton as influenced by breed and chilling duration is presented in Table 6. The bacteria identified are a matter of public health importance that the presence of bacteria capable of causing food poisoning and/or infection be eliminated in animal product through improved handling processes. 
Effect of breed, chilling duration and processed product on the quality characteristics of mutton

Table 5: Microbial count of mutton as influenced by breed and chilling duration

\begin{tabular}{|c|c|c|c|c|c|c|c|c|c|}
\hline \multicolumn{2}{|l|}{ Treatment } & \multicolumn{4}{|c|}{ Bacteria count (cfu/g) } & \multicolumn{4}{|c|}{ Coliform count (cfu/g) } \\
\hline \multicolumn{10}{|l|}{ Breed } \\
\hline Balami & & \multicolumn{4}{|c|}{$4.60 \times 10^{3 a}$} & \multicolumn{4}{|c|}{$3.46 \times 10^{2 b}$} \\
\hline Uda & & \multicolumn{4}{|c|}{$8.90 \times 10^{2 b}$} & \multicolumn{4}{|c|}{$1.10 \times 10^{2 c}$} \\
\hline Yankasa & & \multicolumn{4}{|c|}{$5.35 \times 10^{2 c}$} & \multicolumn{4}{|c|}{$5.90 \times 10^{2 a}$} \\
\hline SEM & & \multicolumn{4}{|c|}{$1.02 \times 10^{2}$} & \multicolumn{4}{|c|}{$0.44 \times 10^{2}$} \\
\hline \multicolumn{10}{|l|}{ Chilling Duration (hrs) } \\
\hline 0 & & \multicolumn{4}{|c|}{$2.25 \times 10^{3 a}$} & \multicolumn{4}{|c|}{$4.49 \times 10^{2 a}$} \\
\hline 24 & & \multicolumn{4}{|c|}{$1.92 \times 10^{3 b}$} & \multicolumn{4}{|c|}{$3.04 \times 10^{2 b}$} \\
\hline 48 & & \multicolumn{4}{|c|}{$1.86 \times 10^{3 \mathrm{~b}}$} & \multicolumn{4}{|c|}{$2.93 \times 10^{2 b}$} \\
\hline SEM & & \multicolumn{4}{|c|}{$1.02 \times 10^{2}$} & \multicolumn{4}{|c|}{$0.44 \times 10^{2}$} \\
\hline \multicolumn{10}{|l|}{ Interaction } \\
\hline $\mathrm{B} \times \mathrm{C}$ & & \multicolumn{4}{|c|}{0.014} & \multicolumn{4}{|c|}{0.696} \\
\hline \multicolumn{10}{|c|}{$\begin{array}{l}\text { abc means within column having different superscripts differed significantly }(\mathrm{P}<0.05), \mathrm{SEM}=\text { Standard } \\
\text { error of mean, } \mathrm{B}=\text { Breed, } \mathrm{C}=\text { Chilling duration; Total Viable Bacteira: Satisfactory }=<10^{4}, \text { Acceptable }= \\
10^{4}-<10^{6} \text {, Unsatisfactory }=>10^{6} \text {; Coliform count: }=<10^{2} \text {, Acceptable }=10^{2}-<10^{4} \text {, Unsatisfactory }=>10^{4}\end{array}$} \\
\hline \multirow{2}{*}{ Bacteria } & \multicolumn{3}{|c|}{ Balami } & \multicolumn{2}{|r|}{ Uda } & & \multicolumn{3}{|c|}{ Yankasa } \\
\hline & $0 \mathrm{hrs}$ & 24 hrs & $48 \mathrm{hrs}$ & $0 \mathrm{hrs}$ & 24 hrs & $48 \mathrm{hrs}$ & $0 \mathrm{hrs}$ & 24 hrs & $48 \mathrm{hrs}$ \\
\hline Bacillus cereus & $\checkmark$ & $\checkmark$ & $\checkmark$ & $x$ & $x$ & $x$ & $x$ & $x$ & $x$ \\
\hline Enterobacter aerogenes & $x$ & $x$ & $\checkmark$ & $\checkmark$ & $\checkmark$ & $x$ & $x$ & $x$ & $x$ \\
\hline Escherichia coli & $\checkmark$ & $\checkmark$ & $x$ & $\checkmark$ & $\checkmark$ & $\checkmark$ & $\checkmark$ & $x$ & $\checkmark$ \\
\hline Klebsiella oxytoca & $\checkmark$ & $\checkmark$ & $\checkmark$ & $x$ & $x$ & $\checkmark$ & $x$ & $x$ & $x$ \\
\hline Proteus mirabilis & $x$ & $x$ & $x$ & $\checkmark$ & $\checkmark$ & $\checkmark$ & $x$ & $\checkmark$ & $x$ \\
\hline Pseudomonas aerugenosa & $x$ & $x$ & $x$ & $\checkmark$ & $x$ & $x$ & $x$ & $x$ & $\checkmark$ \\
\hline Salmonella typhi & $\checkmark$ & $\checkmark$ & $\checkmark$ & $x$ & $\checkmark$ & $\checkmark$ & $x$ & $x$ & $x$ \\
\hline Serratia marcescens & $x$ & $x$ & $x$ & $x$ & $x$ & $x$ & $\checkmark$ & $\checkmark$ & $\checkmark$ \\
\hline Staphylococcus aureus & $x$ & $x$ & $x$ & $x$ & $x$ & $x$ & $\checkmark$ & $\checkmark$ & $\checkmark$ \\
\hline Streptococcus faecalis & $x$ & $x$ & $x$ & $x$ & $x$ & $x$ & $\checkmark$ & $\checkmark$ & $x$ \\
\hline
\end{tabular}

$\checkmark=$ Identified, $x=$ Unidentified

Microbial count of mutton as influenced by breed and processed product

Breed significantly $(\mathrm{P}<0.05)$ affected microbial count in mutton (Table 7). There was an increased in the number of total viable bacteria count and coliform count from the satisfactory range of $\left(<10^{4}\right)$ to acceptable range $\left(10^{4}\right.$ to $\left.<10^{6}\right)$ in mutton as influenced by breed and processed product. This increase might be attributed to contamination by handlers and processors of the meat during processing. There was significant $(\mathrm{P}<0.05)$ effect of processed product on microbial count of mutton (Table 7). As influenced by processed products, Tsire had the highest microbial count and coliform count though it was within the acceptable range. This could be attributed to the fact that Tsire and Balangu have no protection unlike Tukunya which is wrapped. This agrees with Igene and Abulu (1984). 
Salihu, Duru, Abdu, Munza, Abdu, Sadiq and Bamus

Table 7: Microbial count of mutton as influenced by breed and processed product

\begin{tabular}{lcc}
\hline Treatment & Bacteria count (cfu/g) & Coliform count (cfu/g) \\
\hline Breed & $1.73 \times 10^{5 \mathrm{a}}$ & $1.58 \times 10^{3 \mathrm{c}}$ \\
Balami & $7.12 \times 10^{4 \mathrm{~b}}$ & $5.11 \times 10^{3 \mathrm{a}}$ \\
Uda & $4.20 \times 10^{4 \mathrm{c}}$ & $2.48 \times 10^{3 \mathrm{~b}}$ \\
Yankasa & $1.11 \times 10^{4}$ & $0.18 \times 10^{3}$ \\
SEM & & \\
Processed Product & $3.72 \times 10^{4 \mathrm{~b}}$ & $2.14 \times 10^{3 \mathrm{~b}}$ \\
Balangu & $2.14 \times 10^{5} \mathrm{a}$ & $5.83 \times 10^{3 \mathrm{a}}$ \\
Tsire & $3.43 \times 10^{4 \mathrm{~b}}$ & $1.20 \times 10^{3 \mathrm{c}}$ \\
Tukunya & $1.11 \times 10^{4}$ & $0.18 \times 10^{3}$ \\
SEM & & \\
Interaction & 0.000 & 0.051 \\
B $\times \mathrm{P}$ & & \\
\hline abc means within column having different superscripts differed significantly $(\mathrm{P}<0.05), S E M=$ Standard \\
error of mean, B $=$ Breed, $\mathrm{P}=$ Processed product; Total Viable Bacteira: Satisfactory $=<10^{4}$, Acceptable \\
$=10^{4}-<10^{6}$, Unsatisfactory $=>10^{6} ;$ Coliform count: $=<10^{2}$, Acceptable $=10^{2}-<10^{4}$, Unsatisfactory $=>10^{4}$
\end{tabular}

Identified bacteria in mutton as influenced by breed and processed product Bacteria identified in mutton as influenced by breed and processed product is presented in Table 8. The identified bacteria indicate the presence of food poisoning pathogens of public health significance.

Table 8: Identified bacteria in mutton as influenced by breed and processed product

\begin{tabular}{|c|c|c|c|c|c|c|c|c|c|}
\hline \multirow[b]{2}{*}{ Bacteria } & \multicolumn{3}{|c|}{ Balami } & \multicolumn{3}{|c|}{ Uda } & \multicolumn{3}{|c|}{ Yankasa } \\
\hline & Balangu & Tsire & Tukunya & Balangu & Tsire & Tukunya & Balangu & Tsire & Tukunya \\
\hline Bacillus cereus & $\mathrm{X}$ & $\checkmark$ & $\checkmark$ & $X$ & X & X & $\checkmark$ & $\checkmark$ & X \\
\hline Enterobacter aerogenes & $X$ & X & $\checkmark$ & $\checkmark$ & X & $\checkmark$ & X & X & X \\
\hline Escherichia coli & $\mathrm{x}$ & $\checkmark$ & $\checkmark$ & $\mathrm{x}$ & $\checkmark$ & $\mathrm{x}$ & $\checkmark$ & $\checkmark$ & $\mathrm{x}$ \\
\hline Klebsiella oxytoca & $\checkmark$ & $X$ & $\mathrm{x}$ & $\mathrm{x}$ & $\mathrm{x}$ & $\mathrm{x}$ & $\checkmark$ & $\checkmark$ & $\checkmark$ \\
\hline Proteus mirabilis & X & $\mathrm{x}$ & $\checkmark$ & $\mathrm{x}$ & $\checkmark$ & $\checkmark$ & X & X & $\checkmark$ \\
\hline Pseudomonas aerugenosa & $\checkmark$ & $\mathrm{x}$ & $\mathrm{x}$ & $\checkmark$ & $\checkmark$ & $\mathrm{x}$ & $\mathrm{x}$ & $\mathrm{x}$ & $\mathrm{x}$ \\
\hline Salmonella typhi & $\checkmark$ & $\checkmark$ & $\mathrm{x}$ & $\checkmark$ & X & $\mathrm{x}$ & $\checkmark$ & $\mathrm{x}$ & $\mathrm{x}$ \\
\hline Serratia marcescens & $\mathrm{x}$ & $\mathrm{x}$ & $\mathrm{x}$ & $\mathrm{X}$ & $\mathrm{x}$ & $\mathrm{x}$ & $\mathrm{x}$ & $\mathrm{x}$ & $\mathrm{x}$ \\
\hline Shigella dysenteriae & $\mathrm{x}$ & $\mathrm{x}$ & $\mathrm{x}$ & $\mathrm{x}$ & $\mathrm{x}$ & $\mathrm{x}$ & $\mathrm{x}$ & $\checkmark$ & $\mathrm{x}$ \\
\hline Staphylococcus aureus & $\checkmark$ & $\mathrm{x}$ & $\mathrm{x}$ & $\checkmark$ & $\mathrm{x}$ & $\checkmark$ & $\mathrm{x}$ & $\mathrm{x}$ & $\mathrm{x}$ \\
\hline Streptococcus faecalis & $\mathrm{x}$ & $\checkmark$ & $x$ & $\mathrm{x}$ & $\checkmark$ & $\checkmark$ & $\mathrm{x}$ & $\mathrm{x}$ & $\checkmark$ \\
\hline
\end{tabular}

\section{Conclusion}

It was concluded that proximate composition of mutton from the three breeds of sheep (Balami, Uda and Yankasa) show no difference among the breeds. Processed meat products (Tsire, Balangu and Tukunya) obtained from different breeds of Nigerian sheep (Balami, Uda and
Yankasa) are not homogenous in their proximate composition. Tsire from the three breeds (Balami, Uda and Yankasa) has the overall acceptability among the processed product. Fresh mutton can be chilled for 24 to 48 hours with little or no bacteria. The microbial count obtained from the study was within the satisfactory and acceptable range $<3.5 \log$. 


\section{Recommendation}

It was therefore recommended that meat from the three breed of sheep (Balami, Uda and Yankasa) can be consumed fresh or processed into different products (Tsire, Balangu and Tukunya). Also, fresh mutton should be chilled for 24 to 48 hours with little or no bacteria.

\section{References}

Adam, A. A. G., Atta, M. and Ismail, S. H. A. 2010. Quality and sensory evaluations of meat from Nilitic male kids fed on two different diets. Journal of Animal and Veterinary Advances, 9: 2008-2012

Adu, I. F. and Ngere, L. O. 1971. The indigenous sheep of Nigeria. World Review of Animal Production, (3):51-62.

Alam, M. J., Rahman, M. T., Siddique, M. S., Khan, P., Rand, M. F. and R a h m a n, M . B . 2010 . Antibiogram and plasmid profiling of E. coli isolates. Journal of Biological Research, 3: 1-7.

AOAC. 2005. Official Method of Analysis. International, Association of Official Analytical Chemists, 24th edition Washington D.C. USA. Pp 200-210.

Balarabe, S. 2016. Chemical composition and sensor evaluation of fried minced (Dambun nama) processed from different animal species. MSc. Thesis, Animal Production Programme, Abubakar Tafawa Balewa University, Bauchi. Pp. 181

Bopp, C. A., Brenner, F. W., Wells, J. G. and Strockbine, N. A. 1999. Escherichia, Shigella and Salmonella. In: Murray, P. R., Baron, E. J., Pfaller, M. A., Tenover, F. C. and Yolken, R. H. (Eds.), M-Tech Environmental
Health Dissertation. Technikon Pretoria.

Bourn, D., Wint, W. B. R and Wooley, E. 1994. Nigerian Livestock Resource Survey. World Animal Review, 78(1): 49-58.

Bube, M. M. 2003. Nutritional evaluation of meat from various animal species processed by different methods. PhD Thesis, Animal Production Programme, Abubakar Tafawa Balewa University, Bauchi. Pp. 1-115

Duncan, D. B. 1955. Multiple Range and Multiple F-tests. Biometric, 11:142.

Fasae, O. A. and Adelegan, M. 2011. Growth and faecal egg count response of village managed goats to wilted and sun-dried cassava foliage. Journal of Agricultural Science and Environment, 2315 7453.

Fawole, M. O. and Oso, B. A. 2001. Laboratory manul of Mircobiology: Revised edition spectrum books Ltd, Ibadan. Pp. 127.

Hocquette, J. F., Gondret, F., Isaeza, A., Mcdale. F.. Jurie, C. and Pethick, D. W. 2010. Intramuscular fat content in meat producing animals: Development, genetic and nutritional control and identification of putative markers. Animate, 4: 303-319.

IAR 2018. Institute for Agricultural Research, Ahmadu Bello University, Zaria. Meteorological Data Information of Samaru and its Environs.

Igene, J. O. and Abulu,O. E. 1984. Nutritional and Bacteriological Characteristics of Tsire-Type Suya, a Popular Nigerian Meat Product. Journal of Food Protection, 47(3): 
Salihu, Duru, Abdu, Munza, Abdu, Sadiq and Bamus

193-196.

Igene, J. O. and Mohammed, I. D. 1983. Consumers' attitudes towards suya meat product. Annal of Borno, 1: 14

James, G. 1993. Packaging, storage and delivery of ingredients. Journal of Food Technology, 47(8): 54-63.

K' Opondo, F. B. O. 2011. Influence of drying methods and fruit position on the mother plant on seed quality of spider plant (Cleomn gynandra L. Morphotypes) from Western Kenya. Advances in Applied Science Research, 2(3): 74-83.

Kalla, D. J. U., Zahraddeen, D., Abubakar, M., Oladotun, F. B. and Jibia, S. D. 2005. Influence of species and processing method on red meat acceptance among panelists of various cultural background in Bauchi. Journal of Agriculture, Business and Technology, 3(2): 51-57.

Locker, R. H. 1985. Cold-induced toughness of meat. In: Pearson, A. M. and Dutson, T. R. eds. Advances in Meat Research, Publishing Company, Inc., Westport, CT. 1:1-44

March, S. B. and Ratnam, S. 1986. Sorbitol-MAcConkey mediumfor the detection of Escherichia coli 0157:H7 associated with hemorrhagic colitis. Journal of Clinical Microbiology, 23: 869872.

Muhammad, B. F., Muhamood, A. B. and Mustapha, A. 2010. Effects of processing method on composition and consumer acceptability of camel (Camelus dromedaries) meat and beef. Nigerian Journal of Animal Production, 38: 135-143.

Ogbonna, I. O., Danladi, M. S.,
Akinmusire, O. and Odu, C. E. 2012. Microbiological safety and proximate composition of Suya stored at ambient temperature for six hours from Maiduguri, northern Nigeria. Internet Journal of Food Safety, 14: 11-16.

Ojewola, G. S. and Onwuka, G. I. 2001. Evaluation of the organoleptic properties of suya produced from various sources of meat. Nigerian Journal of Animal Production, 28(2): 199-201.

Okonko, I. O., Ukut, O. E., Ikpoh, I. S., Nkang, A. O., Udeze, A. O., Babalola, T. A., Mejeha, O. K. and Fajobi, E. A. 2010. Assessment of bacteriological quality of fresh meats sold in Calabar Metropolis, Nigeria. Electronic Journal of Environmental, Agricultural and Food Chemistry, 9: 89-100.

Ovimap, 2015. Ovi location map: Ovi Earth Imagery Data.

SAS. 2005. Statistical Analysis Software (CD-ROM), Version 8.1, SAS Institute Inc., Cary, N.C., USA.

Savell, J. W. 2012. Beef Carcass Chilling: Current Understanding, Future Challenges. White Paper: Cattlemen's Beef Board and National Cattlemen's Beef Association

Sivasanker, B. 2005. Food Proceessing and Preservation. Prentice-Hall of India Private Limited. Pp. 1-360.

Taiwo, I. O., Olopade, O. A. and Bamidele, N. A. 2017. Microbial load of some imported frozen fish species in Lagos, Nigeria. Nigerian Journal of Animal Production, 44(3): 152-160.

Uzeh, R. E., Ohenhen, R. E. and Adeniji, O. O. 2006 . B a cterial contaminations of tsire-suya, a 
Nigerian meat product. Pakistan Journal of Nutrition, 5(5): 458460.

Wheeler, T. I., Koohmaraie, M. and Crouse, I. D. 1991. Effects of calcium chloride injection and hotboning on the tenderness of round muscle. Journal of Animal Science, 69(12): 4511-4875.

Williams, P. G. 2007. Nutritional composition of red meat. Nutrition \& Dietetics, 64(4): S113-S119.

Yah, S. C., Chineye, H. U. and Eghafona, N. O. 2007. Multi-antibionesresistant plasmid profile of enteric pathogens in pediatric patients from Nigeria. Biochemistry, 19: 35-42.

Zahraddeen, D. 2006. Reproductive performance and milk productivity of goats in Bauchi. PhD thesis, Animal Production Programme, Abubakar Tafawa Balewa University, Bauchi. Pp. 1-145.
Zahraddeen, D., Butswat, I. S. R. and Mbap, S. T. 2006. Preferences for goat meat and milk products consumption in Bauchi State, Nigeria. Animal Production Research Advances, 2(1): 6-11.

Zahraddeen, D., Butswat, I. S. R. and Mbap, S. T. 2007. Comparative study of goat production and management in Bauchi State, Nigeria. International Journal of Tropical Agriculture and Food Systems, 1(4):310-315.

Received: $22^{\text {nd }}$ November, 2019 Accepted: $20^{\text {th }}$ February, 2020 